\title{
Professional conduct during breast and uterine/cervical cancer screening consultations
}

\author{
Conduta de profissionais durante a consulta de rastreio do câncer de mama e útero \\ Conducta de profesionales durante consulta de rastreo del cáncer de mama y útero
}

Fernanda Martins Bertocchi ${ }^{1}$, Betânia Maria Fernandes ${ }^{1}$, Maria Inês Gomes de Almeida ${ }^{1}$, Sandra Carvalho de Freitas $^{2}$, Carla Cardi Nepomuceno de Paiva ${ }^{3}$, Elaine Amaral de Paula ${ }^{1}$

\begin{abstract}
Aimed to evaluate the behavior of professionals regarding checking medical history (anamneses) and the physical examination performed in screening consultation for breast and cervical cancer in primary health care. This is a descriptive cross-sectional study of quantitative analysis, and was conducted in Minas Gerais, MG, Brazil. For evaluation purposes, a structured questionnaire was answered by women who attended a consultation with nurses or doctors, from December 2012 to January 2013. The research instrument contained sociodemographic questions and questions related to medical history (anamneses), physical and gynecological examination, as recommended by the Ministry of Health. Fifty women were interviewed, averaging 40 years of age. The results showed incomplete anamnesis, physical and gynecological examination in all consultations. For full promotion of women's health attention, it is necessary to comply with Ministry of Health recommendations.
\end{abstract}

Descriptors: Women's Health; Comprehensive Health Care; Primary Health Care; Breast Neoplasms; Uterine Cervical Neoplasms.

Objetivou-se avaliar a conduta de profissionais quanto às ações de anamnese e exame físico realizadas na consulta de rastreio de câncer de mama e de colo de útero na atenção primária à saúde. Estudo transversal, descritivo, de análise quantitativa realizado em um município de Minas Gerais, MG, Brasil. Para avaliação, aplicou-se um questionário estruturado às mulheres que compareceram à consulta com profissional enfermeiro ou médico, no período de dezembro 2012 a janeiro de 2013. 0 instrumento de pesquisa, contém perguntas sociodemográficas e referentes às ações de anmnese, exame físico e ginecológico, conforme recomendações do Ministério da Saúde. Foram entrevistadas cinquenta mulheres, com média de 40 anos de idade. Os resultados evidenciaram ações de anamnese, exame físico e ginecológico incompletos em todas as consultas. Para promoção integral da atenção à saúde da mulher faz-se necessário o cumprimento das recomendações do Ministério da Saúde.

Descritores: Saúde da Mulher; Assistência Integral à Saúde; Atenção Primária à Saúde; Neoplasias da Mama; Neoplasias do Colo do Útero.

El objetivo fue evaluar la conducta de profesionales cuanto a las acciones de anamnesis y examen físico realizados en consulta de rastreo de cáncer de mama y de cuello uterino en la atención primaria a la salud. Estudio transversal, descriptivo, cuantitativo realizado en una ciudad en Minas Gerais, MG, Brasil. Para evaluación, se aplicó cuestionario estructurado a las mujeres que fueron a la consulta con el profesional enfermero o médico, de diciembre de 2012 a enero de 2013. El instrumento de investigación tuvo preguntas sociodemográficas y de acciones de anmnesis, examen físico y ginecológico, según recomendación del Ministerio de la Salud. Cincuenta mujeres fueron entrevistadas, con promedia de 40 años de edad. Los resultados señalaron acciones de anamnesis, examen físico y ginecológico incompletos en todas las consultas. Para promoción total de la atención de salud de la mujer, es necesario cumplir con las recomendaciones del Ministerio de la Salud.

Descriptores: Salud de la Mujer; Atención Integral de Salud; Atención Primaria de Salud; Neoplasias de la Mama; Neoplasias del Cuello Uterino.

\footnotetext{
${ }^{1}$ Universidade Federal de Juiz de Fora. Juiz de Fora, MG, Brazil.

${ }^{2}$ Hospital Regional João Penido. Juiz de Fora, MG, Brazil.

${ }^{3}$ Universidade Federal do Estado do Rio de Janeiro. Rio de Janeiro, RJ, Brazil.

Corresponding author: Fernanda Martins Bertocchi

Rua Carangola, 505, Democrata, CEP: 36035-220. Juiz de Fora, MG. Brazil. E-mail: nanda_bertocchi@yahoo.com.br
} 


\section{Introduction}

Cancer has been considered one of the most concerning public health problems of the Brazilian health system due to its epidemiological, social and economic relevance. Sufferering is influenced from internal or external causes in the body; the internal causes are genetically predetermined while external causes are related to environmental influences, and to the habits or customs of society ${ }^{(1)}$.

Breast and cervical cancer are the leading cause of morbidity among women, after non-melanoma skin cancer. Breast cancer is related the early menarche, late menopause, first pregnancy after 30 years of age, nulliparity and postmenopausal hormone replacement therapy ${ }^{(2)}$. On the other hand, cervical cancer is associated with persistent infection by oncogenic subtypes of the Human Papilloma Virus, in particular subtypes 16 and 18, which account for $70 \%$ of cervical cancers ${ }^{(3)}$. Other factors as multiparity, use of oral contraceptives, smoking, early sexual initiation and numerous sexual partners increase the risk of developing this cancer ${ }^{(4)}$.

Estimates for Brazil in 2014 show that 57,120 women will be diagnosed with breast cancer, while 15,590 will be diagnosed with cervical cancer, with an estimated risk of 57 and 15 cases per 100 thousand women $^{(5)}$, respectively.

In Brazil, the National Policy for Integral Attention to Women's Health, Viva Woman's Program and other guidelines for awareness of breast and cervical cancer have undergone changes, with the purpose of reducing morbidity and mortality from such cancers. The gateway for screening and early detection is primary health care through its health centers. Breast and cervical cancer check-up consultations are part of the routine of these health services which are guided by documents that deal with the subject ${ }^{(6)}$. Therefore, it is incumbent that the members of the primary healthcare team provide full health and ongoing attention to the health needs of women; that they refer cases to other needed health care levels with a view to longitudinal care. In this way, breast and uterine cancer screening can contribute a lot to reducing these morbidities and contribute to the early detection of pre-existing diseases, such as cardiovascular.

Tracking the patients' clinical and gynecological history is necessary in cervical and breast cancer screening consultations as such information aids in disease prevention and promotion of health and life quality ${ }^{(7)}$.

Considering the above, it is believed that screening actions are essential for early detection as well as for the prevention of complications related to women's health. In this sense, this study aims to evaluate the behavior of primary care professionals who work in breast and cervical cancer screening consultation as for anamnesis and physical examinations, according to the perception of a group of women responding to the following guiding question: How are knowledge and the actions of primary care professionals during screening consultations of cervical and breast cancer adapted to the recommendations of the Ministry of Health?

With this study we present results that may guide the action plans for screening and early diagnosis of cervical and breast cancer in order to increase the quality and the search and consolidation of comprehensive women's health care.

\section{Methods}

An evaluative study from quantitative data analysis; the evidence and the results of evaluation studies have the potential to interact and to redirect the decision-making process $^{(8)}$.

The investigation occurred in seven primary health care units in the mid-sized town of Zona da Mata, in the state of Minas Gerais, Brazil. Women over the age of 18 who attended the primary health care units for screening consultation of cervical and breast cancer in the days of conducting the research and agreed to participate in the study were the considered 
criteria for inclusion. The study excluded women who did not accept the data collection procedure. Thus, fifty women between 18 and 89 years of age were selected for interviews, and half of them held the consultation with a professional nurse and the other half with medical professional. In all, there were five nurses and five physicians involved.

The Department of Primary Care for the city's health stipulates an optimal number of 20 preventive screenings by professionals every month, totalling 200 preventive screenings in the months studied. Thus, we used the sample calculation for finite populations to quantify the size of the sample, resulting in a sample of 50 women.

As established by the Ministry of Health for the evaluation of gynaecologic cancer prevention consultation, the subcomponents of medical history, a physical examination and pelvic examination were considered. The anamneses includes the reasons that led to searching out the health service; clinical history, encompassing sexual orientation, characteristics of the menstrual cycle, the last menstrual period, age when the women had their first sexual intercourse, number of sexual partners, occurrence of sexually transmitted diseases, type of delivery, number of children and personal and family history of systemic arterial hypertension and diabetes mellitus. The physical and gynaecological examinations consisted of a data collection instrument to check for ocular mucosa; blood pressure and body temperature; heart and lung auscultation; static and dynamic inspection and palpation of the breasts; collection of cervical-vaginal smear; coloration test with iodine (Shiller) and twohand touch.

The consultation time was evaluated by means of a digital stopwatch. Participants were asked about the completion of these steps by the professional who attended them. The interviews were recorded on Moving Picture Experts Group1/2 AudioLayer 4 (MP4) digital media. The research included an examination into the control of cervical and breast cancer consultation stages: clinical history and physical and gynecological examinations.

The variables selected for this study were pre-encoded, stored in Statistical Package for the Social Sciences version 19.0 and submitted to exploratory statistical techniques - mean, standard deviation and frequency distribution ${ }^{(9)}$. The relationship between variables was assessed with chi-square and Student's t-test. The results were presented in tables. The significance level was $0.05,95 \%$ confidence interval.

The confidentiality and anonymity of the patient's responses was guaranteed, as well as the right to refuse to participate. They were also asked to sign the Informed Consent Statement. The study was approved by the Ethics Committee of the Federal University of Juiz de Fora with Protocol 02859012.0.0000.5147. The research was authorized by the Secretariat for primary municipal health. This study does not present a conflict of interest.

\section{Results}

Data analysis for the socio-demographic profile showed a mean age of 40 years (SD \pm 16.14 ), ranging in age between 18 and 89 years. The majority of women (58\%) were less than 40 years of age. Regarding marital status, $44 \%$ said they were married; $38 \%$ were single; $10 \%$ widows; and $8 \%$ were divorced. As for education, $48 \%$ reported having completed elementary school; $16 \%$ had completed primary education; and $36 \%$ had a secondary level. In terms of occupation of the participants, $52 \%$ of them were employed, while $48 \%$ had non-paid work.

Of the 50 women participants, 25 attended their first visit with a nurse; the other 25 with a medical professional.

With regard to questions concerning their history, the most common according to the users were as follows: in $90 \%$ of the visits, the last menstrual period was the most frequent question, $84 \%$ were asked about the characteristics of their menstrual cycle, $76 \%$ on their relationship with their partner, $74 \%$ 
were asked about the reasons to attend the consultation, and $72 \%$ about the number of children.

The questions asked less frequently were about the number of sexual partners (26\%); their sexual orientation (36\%); age at first sexual intercourse (34\%); personal and family history of diabetes mellitus (38\%).

When analyzing the variables related to anamneses done during clinical research and comparing with the professional category showed statistically significant differences related to mode of delivery $(\mathrm{p}<0.031)$, sexually transmitted diseases $(\mathrm{p}<0.005)$, number of sexual partners (0.025), age at first intercourse (0.008), personal history of hypertension (0.0001) and diabetes mellitus (0.0001) (Table 1).

Table 1 - Avaliação de itens investigadas da anamnese por categoria profissional $(n=50)$

\begin{tabular}{|c|c|c|c|c|c|}
\hline \multirow[b]{3}{*}{ Variables } & \multicolumn{4}{|c|}{ Professional category } & \multirow{3}{*}{$\begin{array}{c}P \\
\text { value }\end{array}$} \\
\hline & \multicolumn{2}{|c|}{ Nurse } & \multicolumn{2}{|c|}{ Doctor } & \\
\hline & $\begin{array}{c}\text { Yes } \\
\text { n (\%) }\end{array}$ & $\begin{array}{c}\text { No } \\
\text { n (\%) }\end{array}$ & $\begin{array}{c}\text { Yes } \\
\text { n (\%) }\end{array}$ & $\begin{array}{c}\text { No } \\
\text { n (\%) }\end{array}$ & \\
\hline Type of delivery & $21(79.0)$ & $4(21.0)$ & $14(56.0)$ & $11(44.0)$ & 0.031 \\
\hline $\begin{array}{l}\text { Sexually transmitted } \\
\text { diseases }\end{array}$ & $16(64.0)$ & $9(36.0)$ & $6(24.0)$ & $19(76.0)$ & 0.005 \\
\hline $\begin{array}{l}\text { Number of sexual } \\
\text { partners }\end{array}$ & $10(40.0)$ & $15(60.0)$ & $3(12.0)$ & $22(88.0)$ & 0.025 \\
\hline $\begin{array}{l}\text { Age at first sexual } \\
\text { intercourse }\end{array}$ & $13(52.0)$ & $12(48.0)$ & $4(16.0)$ & $21(84.0)$ & 0.008 \\
\hline $\begin{array}{l}\text { Personal and family } \\
\text { history of hyperten- } \\
\text { sion }\end{array}$ & $17(68.0)$ & $8(32.0)$ & $4(16.0)$ & $21(84.0)$ & 0.0001 \\
\hline $\begin{array}{l}\text { Personal and family } \\
\text { history of mellitus } \\
\text { diabetes }\end{array}$ & $16(64.0)$ & $9(36.0)$ & $3(12.0)$ & $22(88.0)$ & 0.0001 \\
\hline
\end{tabular}

As for the physical and gynecological examinations, it was found that the orientation of the actions was focused on the collection of cervical-vaginal smear, performed in all consultations. The two-hand tou$\mathrm{ch} /$ bimanual exam was performed in $76 \%$ of consultations and palpation of the breasts by touch for $92 \%$ of users.

There were not informed assessments of cardiac and pulmonary auscultation in any consultation. Ocular mucosa was inspected and body temperature was measured in $4 \%$ of the consultations; , static and dynamic inspection of breasts was performed in $14 \%$; and $20 \%$ of participants had their blood pressure measured.

There were no statistical differences in the frequency of the actions reported for breast and cervical examinations during the consultations by professional category (Table 2).

Table 2 - Breast evaluation and two-hand touch exam by professional category $(n=50)$

\begin{tabular}{|c|c|c|c|c|c|}
\hline \multirow{3}{*}{ Variables } & \multicolumn{4}{|c|}{ Professional category } & \multirow{3}{*}{$\begin{array}{c}P \\
\text { value }\end{array}$} \\
\hline & \multicolumn{2}{|c|}{ Nurse } & \multicolumn{2}{|c|}{ Doctor } & \\
\hline & $\begin{array}{c}\text { Yes } \\
\text { n (\%) }\end{array}$ & $\begin{array}{c}\text { No } \\
\text { n (\%) }\end{array}$ & $\begin{array}{c}\text { Yes } \\
\text { n (\%) }\end{array}$ & $\begin{array}{l}\text { No } \\
\text { n (\%) }\end{array}$ & \\
\hline $\begin{array}{l}\text { Static breast } \\
\text { evaluation }\end{array}$ & $5(20.0)$ & $20(80.0)$ & $2(8.0)$ & $23(92.0)$ & $\overline{0.209}$ \\
\hline $\begin{array}{l}\text { Dynamic breast } \\
\text { evaluation }\end{array}$ & $5(20.0)$ & $20(80.0)$ & $2(8.0)$ & $23(92.0)$ & 0.209 \\
\hline $\begin{array}{l}\text { Palpation of the } \\
\text { breasts }\end{array}$ & $23(92.0)$ & $2(8.0)$ & $23(92.0)$ & $2(8.0)$ & 0.695 \\
\hline Two hand touch & $18(72.0)$ & $7(28.0)$ & $20(80.0)$ & $5(20.0)$ & 0.371 \\
\hline
\end{tabular}

In the present study, we observed a statistically significant difference between the prevalence of the Shiller test and the professional category $(\mathrm{p}=0.03)$.

The consultation time revealed a variation between 15 and 40 minutes for the consultations held by nurses; showing an average of 26 minutes per appointment. Doctor consultations showed a variation of 6 to 40 minutes, with an average of 22 minutes. Of the 25 nurse consultations, $16 \%$ were performed in a shorter time than recommended by regulation No. 1101 , which is determined as 20 minutes $^{(8)}$. In doctor appointments, $28 \%$ of visits were less than 15 minutes, a time considered as minimal by the former regulation.

\section{Discussion}

This study shows that the anamneses and physical examinations in the study population are being inadequately performed, and consultation times (by physicians and nurses) are short. In contrast, the pro- 
fessional nurses showed a higher frequency of performing anamnesis actions and the Schiller test when compared to doctors. This difference was not observed regarding physical examinations.

Regarding the participants, it was observed that most of them were less than 40 years old - the age group that corresponds to the reproductive age in women and when screening for cervical cancer is most recommended, as the risk of high-grade lesions is higher ${ }^{(6)}$. The incidence of cervical cancer increases in women between 30 and 39 years of age, reaching its peak in the fifth or sixth decade of life. Even before the age of 25, prevalent human papillomavirus infections and low-grade lesions can spontaneously regress in most cases, and can only be monitored according to clinical guidelines ${ }^{(10)}$.

In addition to age, other types of cofactors such as early sexual initiation and multiple partners are associated with risk of human papillomavirus infection $^{(11)}$. In research conducted in the city of Fortaleza-CE, there was evidence of a higher frequency of women who had their first intercourse between 15 and 20 years of age and approximately one quarter of the respondents reported having had more than three sexual partners. The authors of the study emphasize that adolescents are susceptible to develop cervical cancer due to hormonal instability and increased vulnerability to human papillomavirus infection ${ }^{(12)}$. In this study, it was found that little was asked about the number of sexual partners a woman has had, or the age at which she had her first sexual intercourse. Such questions are considered important as they allow the professional greater insight into the sexual history of the woman and results in relevant guidelines at the time of consultation which may contribute to the use of protective measures against cervical cancer.

The Brazilian recommendation for screening of breast cancer consists of: conducting annual clinical breast examinations; when there is any irregularity or difference detected, diagnostic mammography for women aged 40-49 years old is recommended; a clinical breast examination and mammography scre- ening every two years for women between 50 and 69 years; a clinical breast examination and semi-annual mammography for women with family history related to the mother, the sister or daughter with breast cancer under the age of 50; family history related to the mother, the sister or daughter with breast cancer or bilateral ovarian cancer at any age; male breast cancer history and histopathological diagnosis of proliferative breast lesion with atypia or lobular neoplasia in situ, 5 to 10 years before the age of earlier diagnosis in the family ${ }^{(13-14)}$.

In this study, it was found that about $80 \%$ of professionals do not realize the static evaluation and / or dynamics of the breasts. Corroborating the study on knowledge, attitudes and practices of preventive gynecological examinations for workers of the third sector, it was found that the breast examination was the least known among women, and was not performed in $43 \%$ of consultations ${ }^{(15)}$. The clinical breast exam should be a routine performed by a professional (doctor or nurse) at the time of the gynaecological examination, and aims for cancer detection or any other pathology incident. It requires mandatory propedeutical moments, such as static and dynamic inspection and palpatation ${ }^{(7)}$. The clinical breast exam is understood as part of comprehensive care to women's health and should be conducted in each clinical visit, regardless of age ${ }^{(6)}$. The static and dynamic inspection enables the identification of flattening signs of breast contours; bulging or thickening of the skin of the breast; large asymmetries and differences in skin color, texture, temperature and venous circulation pattern $^{(6)}$. The palpation is performed in order to verify the presence of axillary lymph nodes or supraclavicular nodes and the breasts.

Another relevant aspect of the physical examination in consultation screening for cervical and breast cancer refers to the measurement of blood pressure. In this study, it was observed that the professionals involved in the primary health care of women neglected the practice. It is known that hypertension is part of the set of non-communicable chronic diseases, with 
high prevalence and low screening rates ${ }^{(16)}$. Considering the proposal of comprehensive care to women's health, it is believed that screening consultations within primary health care represents an opportune time for prevention and early intervention practices.

In the present study, it was found also that the nurses spent more time during consultations compared to the time spent by doctors. However, even in consultations which took longer, non-compliance with guidelines established by the Ministry of Health ${ }^{(6.13)}$ could be observed.

A study of women and nurses in the south of the country showed that users found the time of breast and cervical cancer screening consultations insufficient to alleviate all their concerns. In addition, participants reported deficiencies in interpersonal communication with the healthcare worker and the lack of guidance. However, the professionals involved reported a desire to devote more time to consultations with women ${ }^{(17)}$.

In the present investigation, it was also found that nurses were more complete in checking medical history (anamneses) and had a higher prevalence of performing the Shiller test compared to doctors. Diagnostic validity study of the Shiller test in a population of Brazilian women found high sensitivity and specificity satisfactory for the Shiller test when combined with Pap smear. Thus, it is recommended the combined use of these two methods as a screening technique for the general population in all consultations of cervical cancer screening ${ }^{(18)}$.

\section{Conclusions}

At the end of this investigation, it is concluded that the screening consultation for cervical and breast cancer has not been completed as per the Ministry of Health recommendations for the perspective of comprehensive health care, suggesting an inadequacy in consultations with women in the established parameters of the Ministry of Health.

It is necessary to reflect on how the consulta- tions have been developed in the public system, which difficulties the health professionals face in their daily work that prevents them from providing quality service and the barriers imposed by the system itself, which limits the query time of the users/patients and other clients in the Brazilian public health system.

\section{Collaborations}

Bertocchi FM, Fernandes BM and Freitas SC contributed to the strategy, field collection data, analysis, data interpretation, article writing and final approval for publication. Almeida MIG, Paiva CCN and Paula EA contributed to analysis, data interpretation, article writing and final approval for publication.

\section{References}

1. Barrow TM, Michels KB. Epigenetic epidemioloy of cancer.Biochem Bioph Res Commun. [Internet]. 2014 [cited 2014 Sep 3]. Available from: http:// www.ncbi.nlm.nih.gov/pubmed/25124661

2. Screening for Breast Cancer. Topic Page. U.S. Preventive services task force. Agency for healthcare research and quality. [Internet]. 2009 [cited 2014 Sep 3]. Available from: http://www. ahrq.gov/clinic/uspstf/uspsbrca.htm

3. Organização Mundial de Saúde. Centro de Informação sobre Papiloma Vírus Humano (HPV) e o câncer cervical. Papiloma vírus humano e cânceres relacionados no Brasil [Internet]. 2010 [citado 2014 set 3]. Disponívelem: < www.who.int / hpvcentre

4. International Collaboration of Epidemiological Studies of Cervical Cancer. Cervical carcinoma and sexual behavior: collaborative reanalysis of individual data on 15,461 women with cervical carcinoma and 29,164 women without cervical carcinoma from 21 epidemiological studies. Cancer Epidemiol Biomarkers Prev. 2009; 18(4):1060-9.

5. Ministério da Saúde (BR). Estimativa da incidência e mortalidade por câncer no Brasil para 2013. Rio de Janeiro: Instituto Nacional de Câncer; [Internet]. 2013 [citado 2014 set 3]. Disponível 
em: http://www.inca.gov.br/estimativa/2014

6. Ministério da Saúde (BR). Secretaria de Atenção à Saúde. Controle dos cânceres do colo do útero e da mama. Cadernos de Atenção Básica. Brasília: Ministério da Saúde; 2013.

7. Bim CR, Pelloso SM, Carvalho MDB, Previdelli ITS. Early diagnosis of breast and cervical cancer in women from the municipality of Guarapuava, PR, Brazil. Rev Esc Enferm USP. 2010; 44(4):940-6.

8. Bodstein R. Processo decisório e avaliação em saúde: ampliando o debate sobre o Programa Saúde da Família. Ciênc Saúde Coletiva. 2009; 14(2):1336-45.

9. Data Mining andStatiscalSolutions. Tecnologia de Análise Preditiva [Internet]. 2011 [citado 2014 ago 20]. Disponível em: http://www.spss.com.br

10. Ministério da Saúde (BR). Instituto Nacional de Câncer. Divisão de Apoio à Rede de Atenção Oncológica. Programa Nacional de Controle do Câncer do Colo do Útero. Brasília: Instituto Nacional de Câncer; 2011.

11. Santos UM, Souza SEB. Papanicolaou: diagnóstico precoce ou prevenção do câncer cervical uterino? Rev Baiana Saúde Pública. 2014; 37(4):941-51.

12. Diógenes MAR, Cesarino MCF, Jorge RJB, Queiroz INB, Mendes RS. Fatores de risco para câncer cervical e adesão ao exame papanicolau entre trabalhadoras de enfermagem. Rev Rene. 2012;
13(1):200-10.

13. Ministério da Saúde (BR). Instituto Nacional de Câncer. Coordenação Geral de Ações Estratégicas. Divisão de Apoio à Rede de Atenção Oncológica. Sismama: informação para avanço das ações de controle do câncer de mama no Brasil. Brasília: Instituto Nacional de Câncer; 2010.

14. Ministério da Saúde (BR). Instituto Nacional de Câncer. Rede Nacional de Câncer Familial: manual operacional. Rio de Janeiro: Instituto Nacional de Câncer; 2009.

15. Afonso VW, Ribeiro LC, Bertocchi FM, Diniz ALL, Passos CS, De Paula EA. Conhecimentos, atitudes e práticas acerca de exames ginecológicos preventivos por trabalhadoras do terceiro setor. HU Rev. 2011; 37(4):431-9.

16. Rosário TM, Scala LCNS, França GVA, Pereira MRG, Jardim PCBV. Prevalência, controle e tratamento da hipertensão arterial sistêmica em Nobres, MT. Arq Bras Cardiol. 2009; 93(6):672-8.

17. Teixeira CAB, Silva RM, Rodrigues MSP, Linard AG, Diógenes MAR, Mendonça FAC. Comunicação interpessoal como instrumento que viabiliza a qualidade da consulta de enfermagem ginecológica. Rev APS. 2009; 12(1):16-28.

18. Russo E, Kupek E, Zanine RM. High grade CIN diagnosis by combined visual inspection with Lugol's iodine and cytology in symptomatic women. Eur J Obstet Gynecol Reprod Biol. 2011; 156(1):91-5. 